\title{
Między pamięcią a historią: animowana rewolucja irańska
}

\author{
$\underline{\text { ELŻBIETA WIACEK }}$ \\ (...) często ci, co obalili dyktatora, mimowolnie \\ i brew sobie działaja jako jego spadkobiercy, kon- \\ tynuujac swoja postawa i sposobem myślenia epoke, \\ którą sami zniszczyli. \\ Ryszard Kapuściński (Szachinszach)
}

W lutym 2019 r. Iran, w Europie dawniej znany jako Persja, celebrował 40 rocznicę rewolucji, która obaliła rządy szacha Mohammada Rezy Pahlawiego i do dziś pozostaje najważniejszym świętem państwowym. 1 lutego 1979 r. przywódca opozycji - wielki ajatollah Ruhollah Chomeini powrócił z wygnania do ojczyzny. W 2019 r. na pamiątkę jego powrotu śmigłowce zrzuciły kwiaty wzdłuż trasy od lotniska do cmentarza Beheszt-e-Zahra w Teheranie, gdzie duchowny został pochowany. Prezydent Iranu Hasan Rouhani w oficjalnym przemówieniu oznajmił, że rewolucja uwolniła kraj od tyranii, kolonizacji i zależności ${ }^{1}$. W stolicy i w innych miastach Iranu przez dziesięć dni gromadziły się setki tysięcy osób, celebrując jubileusz. Mimo że współcześnie wielu Irańczyków kwestionuje fundamentalizm muzułmański, liczny udział w uroczystościach dowodzi, że procesy uruchomione przez rewolucję okazały się długotrwałe.

Na czym polegał fenomen irańskiej rewolucji? Dlaczego przybrała ona obrót niespodziewany dla wielu protestujących? Gdzie szukać jej genezy? Korzenie ruchu rewolucyjnego sięgają okresu konstytucyjnego w Iranie na przełomie XIX i XX w. W efekcie procesów modernizacyjnych zderzyły się różne rozumienia słowa „państwo”: pierwsze - oparte na władzy absolutnej elity rządzącej, drugie reprezentowane przez szyickie duchowieństwo, które wyobrażenie państwa opierało na przekazie Koranu ${ }^{2}$. Trzecią wizję kształtowali zainspirowani Europą irańscy reformatorzy, dla których państwo było własnością narodu ${ }^{3}$. Próbom transformacji państwa w taki sposób, by stało na straży wolności i dobrobytu towarzyszył proces przekształcania się irańskiego „ludu” w „naród” w znaczeniu nowożytnym: wspólnoty obywateli, którzy chcą uczestniczyć w tworzeniu państwa i chronić Iran przed wyzyskiem ze strony potęg kolonialnych ${ }^{4}$.

Na temat rewolucji w Iranie powstała niezliczona ilość książek, artykułów, filmów. Większość z nich koncentruje się na tzw. kryzysie zakładników w latach 1979-1981 i uratowaniu sześciu amerykańskich dyplomatów z Teheranu. Wydarzenia te opisują: amerykański miniserial Na skrzydłach ortów (On Wings of Eagles, reż An- 
drew V. McLaglen, 1986), film telewizyjny Escape from Iran: The Canadian Caper (reż. Lamont Johnson, 1981) oraz produkcje znacznie późniejsze: thriller Operacja Argo (reż. Ben Affleck, 2012) i kanadyjski dokument Nasz człowiek w Teheranie (Our Man in Tehran, reż. Drew Taylor, Larry Weinstein, 2013). Druga grupa filmów skupia się na dramatycznych losach ostatniego szacha, np. irański dramat historyczny Tajemnica szacha (Mo'ammāye shāh, reż. Mohammad Reza Varzi, 2017) oraz dokument A Dying King - The Shah of Iran (reż. Bobak Kalhor, 2017). Wśród filmów o irańskiej rewolucji zdecydowanie wyróżnia się Persepolis (2007) - francuski pełnometrażowy film animowany w reżyserii Marjane Satrapi i Vincenta Paronnauda. Opowiada historię dorastania dziewczynki na tle przewrotu w Iranie, dalszych losów bohaterki na emigracji w Austrii, a następnie jej perypetii po powrocie do Iranu. Podstawą animacji był autobiograficzny komiks Satrapi o tym samym tytule. Żaden z fabularnych przekazów audiowizualnych dotyczących rewolucyjnych wydarzeń nie zyskał takiego rozgłosu i popularności w świecie Zachodu. Dlaczego to właśnie film rysunkowy sprawił, że wydarzenia z izolowanego od czterech dekad kraju utożsamianego z islamskim fanatyzmem stały się bliskie wielu widzom na całym świecie?

Częściowej odpowiedzi dostarcza sukces pierwowzoru Persepolis. Bestsellerowy komiks Marjane Satrapi ukazał się po raz pierwszy we Francji w latach 2000-2003 (wydany w czterech częściach) ${ }^{5}$. Chociaż krytycy często określają go mianem ,powieść graficznej”, której kryteria bez wątpienia spełnia, sama autorka preferuje termin ,komiks” z uwagi na jego bezpretensjonalność i skojarzenia z humorem ${ }^{6}$. Ten bardzo osobisty, bezkompromisowo szczery ,pamiętnik” w formie minimalistycznej, czarno-białej narracji obrazkowej to zarazem zarys najnowszej historii Iranu: upadku reżimu ostatniego szacha, apogeum ruchu rewolucyjnego i jego skutków oraz wojny z Irakiem. Główną bohaterką Persepolis jest dziewczynka (a potem młoda kobieta) o imieniu Marjane, ale na komiks składa się kilkanaście opowieści, opisujących ponad pięćdziesiąt lat z historii irańskiej rodziny Satrapi. Jednostkowy dramat bohaterki i jej najbliższych staje się metonimią dramatów milionów Irańczyków, którzy inaczej wyobrażali sobie przyszłość po przewrocie w 1979 r. Rysunkowa autobiografia Satrapi spotkała się zainteresowaniem czytelników na całym świecie (została przetłumaczona na wiele języków) i uznaniem krytyków, którzy porównali ją do Maus Arta Spiegelmana i wyróżnili nagrodą na międzynarodowym festiwalu komiksu w Angoulême ${ }^{7}$.

Marjane Satrapi urodziła się w 1969 r. w mieście Rasht, w inteligenckiej rodzinie z klasy średniej. Dorastała w Teheranie, gdzie uczyła się w Lycée Français. Jako dziecko, a później nastolatka była świadkiem irańskiej rewolucji, powstania i rozwoju Islamskiej Republiki Iranu ${ }^{8}$ i pierwszych lat wojny z Irakiem. W 1983 r., w związku z coraz trudniejszą sytuacją w kraju, czternastoletnia Marjane została wysłana przez rodziców do Wiednia, by tam kontynuować edukację w liceum francuskim ${ }^{9}$. Pobyt na emigracji zakończył się dla niej dramatycznie: wyalienowana społecznie, po trzymiesięcznym życiu na ulicy i ciężkim ataku zapalenia płuc, w wieku 19 lat wróciła do Iranu. Podjęła studia na Uniwersytecie Azad w Teheranie (największej prywatnej uczelni w Iranie) na wydziale komunikacji wizualnej i poślubiła weterana wojny iracko-irańskiej. Trzy lata później rozwiodła się i wyjechała do Strasburga. Obecnie od wielu lat żyje we Francji. Nie wiadomo, kiedy będzie mogła powrócić do ojczyzny - jej dzieła budzą silne kontrowersje irańskich władz i można je zdobyć wyłącznie na czarnym rynku. 


\section{ELŻBIETA WIĄCEK}

Filmową adaptację Persepolis Satrapi zrealizowała we współpracy z Vincentem Paronnaudem, jednym z najważniejszych niezależnych twórców komiksów ${ }^{10}$. Wspólnie napisali scenariusz i wyreżyserowali film, co było dużym wyzwaniem. Satrapi podkreślała, że komiks ma zupełnie inną formę narracyjną niż film i przeniesienie opowieści na ekran było ryzykowne: Komiks nie jest filmowym scenopisem. Musieliśmy nauczyć się od samego poczatku języka filmowego ${ }^{11}$. Prace nad filmem trwały prawie trzy lata, nad rysunkami pracowało dwudziestu animatorów pod kierunkiem Christiana Desmares'a. Rysunkowym postaciom głosu użyczyły m.in. Catherine Deneuve i Chiara Mastroianni.

Producenci filmu - Marc-Antoine Robert i Xavier Rigault z 2.4.7. Films - początkowo byli przeciwni animacji z uwagi na poziom trudności i rozważali produkcję filmu z udziałem prawdziwych aktorów ${ }^{12}$. Satrapi nie zgodziła się jednak argumentując, że rezultatem $w$ najlepszym wypadku byłaby egzotyczna historia, a w najgorszym - historia z Trzeciego Świata ${ }^{13}$. Obawy te wydają się uzasadnione - dla widzów z Zachodu bohaterowie „z krwi i kości”, charakteryzujący się bliskowschodnim wyglądem, zapewne wpisywaliby się w kategorię Obcego i budzili określone stereotypy. W dodatku do wydania DVD Satrapi wyjaśnia: nie chciałam, aby postaci $w$ filmie wygladaty jak cudzoziemcy $w$ dalekim, obcym kraju, ale jak zwykli ludzie w jakimś kraju. W ten sposób chciałam pokazać, jak łatwo dowolne państwo może szybko stać się takie jak obecnie Iran. Technika animacji pozwoliła wyjść filmowej historii poza wymiar partykularny; zdaniem Satrapi rysunek to najbardziej uniwersalny język, jaki może istnieć, a zarazem bardziej reprezentatywny dla prawdy niż fotografia, jako że wyraża subiektywność osoby, która go tworzy: To jest język, który trafia do wszystkich. Jeżeli narysuję kogoś, kto jest smutny, to nie ma takiej kultury na świecie, $w$ której by powiedziano, że ten człowiek jest szczęśliwy. Ta cecha rysunku pozwoliła mi dotrzeć do języka międzynarodowego, a także zachować moje poczucie humoru ${ }^{14}$.

Narracja filmu Persepolis ma formę retrospekcji. Na paryskim lotnisku młoda kobieta stoi przed tablicą odlotów. Jej wzrok zatrzymuje się na wyświetlonej informacji o locie do Teheranu. Wkłada czarną chustę i ustawia się w kolejce do wejścia na pokład. Kiedy jednak obsługa prosi ją o okazanie biletu i paszportu, kobieta bez wyjaśnienia odchodzi ze smutkiem i zrezygnowana siada w poczekalni, zapalając papierosa. Jego dym przeobraża kolorową tonację kadru w czarno-białą, przenosząc widzów ze współczesnej Francji w inną czasoprzestrzeń - do roku 1978 w Teheranie. Dziewięcioletnia dziewczynka imieniem Marji radośnie wita na lotnisku powracającą z Paryża ciocię, wypytując, czy widziała wieżę Eiffla i Bruce’a Lee. Wspomnienia Marjane są czarno-białe z dodatkiem odcieni szarości. Tą zredukowaną tonacją barwną autorka chciała nawiązać do azjatyckiego teatru cieni, który trafił do Europy w XVIII w. Posłużyła się tym zabiegiem, wychodząc z założenia, że taka bajkowość, wspólna wszystkim kulturom, łatwiej przeniesie widzów w świat dzieciństwa.

Wkraczamy w życie małej bohaterki i jej rodziny, kiedy niezadowolenie społeczeństwa irańskiego osiąga apogeum. Zza okna dobiegają okrzyki protestujących, głośno skandujących „Precz z szachem!”. Ojciec Marjane jest podekscytowany historyczną chwilą, a babcia ze spokojem i zadowoleniem komentuje rozruchy, zarzucając władcy proamerykańskie sympatie. Dziewczynka jest zdezorientowana krytyczną postawą bliskich: zgodnie z przekazaną jej w szkole prorządową propa- 
gandą szach został wybrany przez Boga. Ojciec, aby w prosty sposób wyjaśnić córce dziejowe zawiłości, a zarazem uświadomić jej prawdę o bieżących wydarzeniach, skrótowo i celnie relacjonuje ostatnie 50 lat historii Iranu. Cofa się do drugiej dekady XX w.: schyłku dynastii Kadżarów w Persji i obalenia jej rządów w 1921 r. Narracja ojca akcentuje aktywny udział Anglików w przewrocie oraz ich wpływ na ostateczny ustrój polityczny kraju. Powodem uzależnienia Iranu od Wielkiej Brytanii była nie tylko przegrana wojna (1857), ale także dążenie do modernizacji kraju z pomocą Zjednoczonego Królestwa i oddanie brytyjskim firmom kontroli nad niemal całą nowoczesną infrastrukturą gospodarczą kraju. Wielka Brytania, dążąc do utrzymania wpływów w Iranie, przekonała dowódcę perskiej Brygady Kozackiej Rezę-chana do zamachu stanu. Filmowa konwersacja trafnie oddaje charakter ówczesnych przemian: - Co mam robić? - Nic. Daj nam ropę, a my zadbamy o resztę. Reza-chan początkowo dążył do ustanowienia w Iranie republiki. Anglicy przekonali go jednak, aby nie rezygnował z monarchii, gdyż dzięki niej skupi całą władzę, a Iran potrzebuje silnego przywódcy. W 1925 r. Reza-chan doprowadził do detronizacji Kadżarów przez irańskie zgromadzenie narodowe Madżlis i do zatwierdzenia swojego wyboru na nowego szacha ${ }^{15}$.

Ojciec Marjane sprawiedliwie podsumowuje rządy Rezy Szaha Pahlawiego, doceniając wprowadzone przezeń zmiany. Zostat dyktatorem, ale zmodernizowat Iran. Na swój sposób kochat kraj, inaczej niż jego następca. Gdy na arenę polityczną wkracza syn - Mohammad Reza Pahlawi - ujawnia się jego megalomania. Jestem świattem Ariów! - krzyczy nowy władca, usuwając wszystkich z drogi do tronu - Dzięki mnie Iran stanie się niezwykle nowoczesny. Nasz lud odzyska dawna chwałę. Scena ta znakomicie oddaje model sprawowania władzy, cechujący się autorytaryzmem, rozmachem zamierzeń i totalnością projektów, ale także marzycielstwem i poczuciem własnej wyjątkowości połączonym z pragnieniem wpisania się w kulturę zachodnią. Modernizacja, tożsama z amerykanizacją, miała objąć wszystkie dziedziny życia ${ }^{16}$. Kierunek reform, wytyczony pod wpływem amerykańskich doradców i uwzględniający interesy USA, nie brał pod uwagę dążeń całego narodu. W efekcie narastał konflikt między wąską grupą elity związanej z władzą a rzeszą niższych warstw społecznych. Bez współpracy z intelektualistami szach nie był w stanie zagospodarować potencjału społeczeństwa uruchomionego przez wpływy z Zachodu ${ }^{17}$. W poszukiwaniu centralnej determinanty kulturowej zwrócił się ku pojęciu demokracji, chociaż władca (mający mgliste wyobrażenie na jej temat) nie łączył jej z rządami prawa i wolnością obywateli, lecz z ich samodyscypliną ${ }^{18}$. Jak zauważa Ryszard Kapuściński w książce Szachinszach, reportażu z Iranu napisanym trzy lata po rewolucji, Mohammad Reza był osobą mało popularną w kraju, obracał się jedynie w najwyższych kręgach wojskowych i nie zdawał sobie sprawy z pogardy, jaką wobec niego żywili rodacy ${ }^{19}$.

Opowieść ojca jest przedstawiona w formie odróżniającej się od reszty animacji i odwołującej się do konwencji teatru lalkowego funkcjonującego na obszarze Persji już od XI w. Znany był on zarówno jako teatr cieni (saje-bazi), jak i taki, w którym występowały lalki (chejme-je szab-bazi) ${ }^{20}$. Podstawowe fabuły lalkarz modyfikował, wykorzystując je jako pretekst do aluzji i satyry społecznej. W Persepolis konwencja ta ma walor nie tylko estetyczny - dobitnie ukazuje, że obaj przedstawiciele dynastii Pahlawich na scenie historii byli marionetkami w rękach obcych mocarstw. 
W animowanej historii Iranu dzieje kraju przeplatają się z historią rodzinną. Marjane dowiaduje się, że jej dziadek był prześladowany przez pierwszego szacha Pahlawiego z dwóch powodów - był księciem ze zdetronizowanej dynastii Kadżarów, a ponadto był komunistą. Wątek ten nie jest fikcyjny: matka Satrapi była prawnuczką Szaha Nasser-al-Din, który władał Persją w latach 1848-1896. Sama autorka Persepolis z właściwą sobie autoironią komentuje swoje arystokratyczne pochodzenie: Królowie z dynastii Qajar mieli setki żon i tysiące dzieci. Jeśli wziać pod uwagę wszystkie pokolenia, otrzyma się dziesięć lub piętnaście tysięcy księżniczek $i$ książą. Nie ma $w$ tym nic specjalnego ${ }^{21}$. Paradoksalne zestawienie „książę komunista" także nie jest fantazją. Za panowania Rezy Szaha ideologiczny krajobraz Iranu był niezwykle różnorodny - debaty na temat nowego kształtu kraju toczyły się między ruchami lewicowymi, nacjonalistami oraz grupami islamskimi ${ }^{22}$. W nurcie lewicowym najpotężniejsza była partia Tude, powstała po abdykacji władcy w 1941 r. i zwolnieniu z więzienia aresztowanych marksistów ${ }^{23}$. Na jej czele stanął kadżarski książę Sulejman Eskandari ${ }^{24}$. Na jego żądanie Tude unikała haseł antyreligijnych, ograniczając się do wezwań do radykalnej przebudowy porządku społecznego ${ }^{25}$.

Kwestie reform społecznych absorbują także Marjane wzrastającą w atmosferze fermentu politycznego. Buntownicza i bezkompromisowa dziewczynka (zamierzająca w przyszłości zostać prorokinią) dyskutuje z rodziną i z Bogiem o wydarzeniach rozgrywających się w Iranie, przedstawiając własną wizję kraju idealnego: Po pierwsze: wszyscy musza być grzeczni. Po drugie: każdy musi dotrzymywać słowa. Po trzecie: każdy musi być dobry. Po czwarte: biedni maja zjadać co dzień pieczonego kurczaka. Po piate: stare kobiety nigdy nie będa cierpiały. Postulaty te można zbyć uśmiechem jako pobożne życzenia egzaltowanego dziecka, ale można je również odczytać jako aluzję do społecznych utopii; albo bardziej partykularnie - do reform zainicjowanych przez Mohammada Rezę Pahlawiego. W 1963 r. władca postanowił przeprowadzić program kompleksowych reform nazwanych „białą rewolucją”, mającą zapoczątkować proces modernizacji Iranu na wzór zachodni. Program obejmował m.in. rozwinięcie systemu szkolnictwa i służby zdrowia oraz nadanie kobietom praw wyborczych ${ }^{26}$. Szach miał nadzieję, że przemiany podniosą poziom życia społeczeństwa, zwłaszcza jego uboższych warstw. Pomimo rozmachu, z jakim przystąpiono do realizacji programu, tylko w małej części przyniósł on spodziewane efekty ${ }^{27}$. Reforma rolna, której celem było przekazanie ziemi (należącej do monarchy i duchowieństwa) pracującym na niej chłopom, w praktyce doprowadziła do jeszcze większego rozwarstwienia ${ }^{28}$. Niedostosowanie planów do warunków dotyczyło również innych obszarów, np. zapewnienie jednej szklanki mleka dziennie każdemu uczniowi przekraczało możliwości produkcyjne przemysłu mleczarskiego ${ }^{29}$. Ogromny rozdźwięk między górnolotną wizją szacha Pahlawiego a rzeczywistymi możliwościami jej realizacji znajduje analogię w idealistycznym myśleniu małej Marjane, która na pytanie babci: Jak sprawisz, żeby staruszki nie cierpiały, bez wahania odpowiada: To będzie zakazane!

Rozgoryczenie Irańczyków spowodowane niepowodzeniem reform spotęgowała jeszcze bezwzględna likwidacja opozycji - wielu współpracowników i zwolenników obalonego premiera Mossadegha ${ }^{30}$ oraz kilkuset członków partii Tude zostało poddanych torturom, straconych lub uwięzionych ${ }^{31}$. Samo podejrzenie o nieprzychylność wobec władzy szacha groziło aresztowaniem. Temat brutalnych 
represji pojawia się w Persepolis wielokrotnie. W jednej z pierwszych scen widzimy rodzinę Marjane bawiącą się na prywatnym przyjęciu przy muzyce disco. Wesołą atmosferę mąci rozmowa ojca $\mathrm{z}$ koleżanką opowiadającą o krytycznym stanie męża od czterech lat torturowanego w więzieniu.

Za terrorem w Iranie w latach 60. i 70. stał SAWAK ${ }^{32}$ - siejąca postrach organizacja rządowa łącząca kompetencje policji politycznej, wywiadu i kontrwywiadu, której podstawowym celem było zwalczanie opozycji ${ }^{33}$. Jej agenci inwigilowali obywateli w każdej dziedzinie życia, a w przypadku zarzutów o działalność na szkodę państwa stosowali tortury często prowadzące do śmierci przesłuchiwanych. W wypowiedziach dla prasy zagranicznej szach zaprzeczał informacjom o brutalnych metodach ${ }^{34}$. Fragmenty wywiadów telewizyjnych z jego udziałem oraz wstrząsające świadectwa byłych więźniów politycznych zostały udokumentowane w filmie These Walls Will Talk zrealizowanym w 2016 r. przez irańską sieć telewizyjną PressTV (właściciel: Islamic Republic of Iran Broadcasting) i udostępnionym na kanale YouTube ${ }^{35}$.

W reakcji na dyktatorskie rządy nasiliła się działalność zbrojnej opozycji islamskiej i lewicowej. Wypchnięte ze sceny politycznej duchowieństwo szyickie zyskało nową siłę, ponieważ ogromna część społeczeństwa darzyła ulemów szacunkiem ${ }^{36}$. Wizję kraju poddanego westernizacji Irańczycy odrzucili jako obcą, odpowiadając hasłem Chomeiniego: „Szach musi odejść!”. Minimalistyczny styl animacji w Persepolis sprawia, że rewolucja traci lokalny charakter. Kiedy rozruchy przybierają na sile, widzimy tylko sylwetki demonstrujących w starciu z policją i wojskiem. Natomiast przedstawiciele aparatu represji noszą maski gazowe, trzymają broń lub kryją się we wnętrzach czołgów. Obrazy te - budzące skojarzenia ze stylistyką ekspresjonizmu niemieckiego - są pozbawione narodowych czy etnicznych odniesień: nie znajdziemy ich ani w rysach twarzy postaci, ani w ich ubiorze czy w pejzażu miasta. Owładnięty rewolucją Teheran nie ma żadnych cech charakterystycznych - jest po prostu dużym nowoczesnym miastem. Zabity przez żołnierzy anonimowy demonstrant niesiony na ramionach innych protestujących staje się uniwersalnym znakiem oporu przeciw reżimowi.

Po serii zamieszek w 1978 r. szach wykonał wyraźny gest pod adresem opozycji islamskiej, zamykając bary i kasyna i uwalniając więźniów politycznych. Działania te nie wystarczyły jednak do zakończenia protestów - chaos w państwie narastał ${ }^{37}$. Filmy dokumentalne dotyczące rewolucji islamskiej (np. Iran: A Cinematographic Revolution, reż. Nader T. Homayoun, 2007) akcentują utrwaloną przez reporterów przełomową chwilę: Mohammad Reza Pahlawi z żoną Farah Dibą wsiadając do samolotu deklaruje, że wyjeżdża na wakacje (z których miał już nigdy nie powrócić). Persepolis nie ukazuje tej ikonicznej sceny. W eliptycznej narracji, opartej na selektywnej pamięci dziecka, kulminację kryzysu reprezentuje migawka z telewizji ukazująca fragment przemówienia zdesperowanego władcy, który zwraca się do swoich obywateli: Rozumiem wasz bunt. Razem spróbujemy zbudować demokrację. Zadbajmy o nasza przyszłość. Demagogia ta nie robi wrażenia na Irańczykach. W kolejnej scenie widzimy thum obalający pomnik szacha i wiwatujący, gdy obwiązany sznurami posąg spada z cokołu.

Aluzje do przewrotu politycznego można też dostrzec w scenie o bardziej osobistym charakterze. Rodziców Marji odwiedza uwolniony po latach z więzienia przyjaciel Siamak. Towarzysząca mu córka z dumą obwieszcza: Mój tato jest bo- 


\section{ELŻBIETA WIĄCEK}

haterem. W poruszającej relacji Siamak opisuje wyrafinowane tortury, jakie testowali na nim profesjonalni oprawcy SAWAK-u, ujawniając, że: Ludzi od tortur szkoliła CIA, znali się na swojej robocie. SAWAK utrzymywał ścisłe stosunki z CIA, pozwalając jej na korzystanie z terytorium Iranu do działań wywiadowczych wymierzonych w Związek Radziecki ${ }^{38}$.

Skąd wzięła się gotowość Irańczyków do obalenia szacha? Wynikała z uwarunkowań historycznych - już od upadku dynastii Safawidów ${ }^{39}$ w XVIII w. mamy do czynienia z brakiem legitymizacji władzy w Iranie ${ }^{40}$. Saïd Arjomand zauważył, że ten przedłużający się kryzys zapoczątkował rozwój abstrakcyjnej idei „państwa irańskiego" i uwolnił ją od koncepcji rządów dynastycznych jako władzy z woli Boga ${ }^{41}$. W czasach dynastii Kadżarów faktyczna władza szacha obejmowała niewielki obszar Iranu, z Teheranem jako centrum, natomiast zasięg wpływów na pozostałych obszarach był nieustannie negocjowany z wodzami plemion oraz duchownymi szyickimi ${ }^{42}$. Pozycja przywódcy zależała od jego siły, zdolności do utrzymania porządku i umiejętnego pełnienia funkcji. Jeśli przywódca nie spełniał oczekiwań społeczeństwa, bunt był zgodny z prawem ${ }^{43}$. Żadne z wcześniejszych wystąpień opozycji wobec szacha nie angażowało jednak tak szerokich warstw społecznych jak to w latach 70. XX w. Hasłami rewolucji były: zlikwidowanie despotyzmu, zaprowadzenie sprawiedliwości społecznej i usunięcie wpływów obcych państw.

W przeciwieństwie do propagandowych filmów irańskich gloryfikujących rewolucję, w Persepolis przełom polityczny jest ukazany z dystansu i z dużą dozą ironii. W warstwie obrazowej transformację śledzimy z punktu widzenia małej Marji, lecz sarkastyczny komentarz z offu bez wątpienia należy do dorosłej już bohaterki. Rozpamiętując swoją irańską przeszłość, Marjane kpi z eksplozji porewolucyjnej bohaterszczyzny: Po wyjeździe szacha kraj na kilka miesięcy popadt $w$ euforię. Każdy stat się rewolucjonista $i$ walczyt z szachem. Znamię naszej sasiadki nagle stało się wojenna blizną. (...) wczorajsi wrogowie stali się narodowymi bohaterami. W towarzyszącą obrazom narrację Marjane-kobiety wplatają się spostrzeżenia Marjane-dziewczynki, która zauważa brak konsekwencji w postępowaniu dorosłych oraz ich hipokryzję: Nauczycielka, która kochała szacha, kazała nam wydzierać z książek zdjęcia królewskiej rodziny.

W porewolucyjnym chaosie w życie małej bohaterki wkracza stryj Anusz, idealistyczny marksista, który za swoje poglądy spędził 9 lat w więzieniu. Jak wielu innych więźniów politycznych, wyszedł na wolność po ucieczce szacha. Zainteresowanej jego przeszłością bratanicy Anusz opowiada o pracy dla stryja Ferejduna, ministra sprawiedliwości w niepodległej od 1918 r. Demokratycznej Republice Azerbejdżanu (który od XV do XVIII w. był częścią Iranu, a następnie Imperium Rosyjskiego). Narracja Anusza jest świadectwem rozprzestrzeniania się w Azji nowych idei społeczno-politycznych: Demokracja opiera się na sprawiedliwości. Wobec prawa wszyscy sa równi. Popiera Ferejduna w jego planach uwolnienia Iranu od szacha, ale historia pisze inny scenariusz - do Azerbejdżanu wkracza Armia Czerwona i minister zostaje stracony. Naznaczony etykietką wroga politycznego i ścigany przez wojsko szacha Anusz nie może zostać w Iranie. Udaje się na wygnanie do ZSRR, gdzie robi doktorat z marksizmu i leninizmu. Stęskniony za ojczyzną próbuje wrócić z fałszywymi dokumentami, ale zostaje rozpoznany i aresztowany. Zasłuchanej w jego historię bratanicy wyznaje: Mówię ci to, bo musisz o tym wiedzieć. Pamięć musi przetrwać w rodzinie, nawet jeśli trudno ci to zrozumieć. 

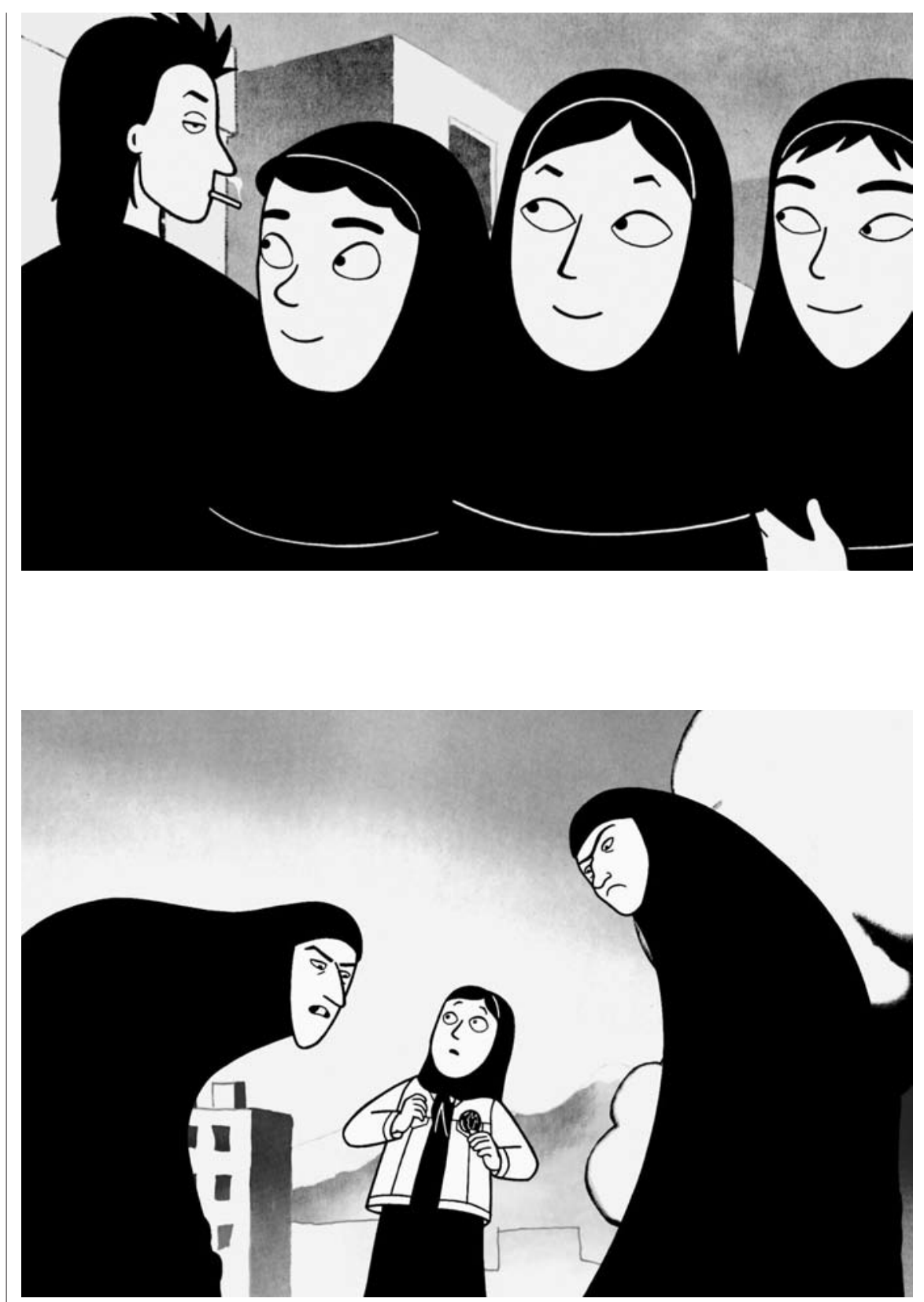

Persepolis, reż. Marjane Satrapi, Vincent Paronnaud (2007) 


\section{ELŻBIETA WIĄCEK}

Rewolucyjne siły w Iranie szybko przeszły od chaotycznej aktywności do zinstytucjonalizowanego działania. Rząd kierowany przez Mehdiego Bazargana sprawował władzę tylko teoretycznie - w praktyce przejął ją Chomeini wraz ze swoimi rewolucyjnymi instytucjami ${ }^{44}$. Nowa władza natychmiast rozpoczęła stanowienie nowego prawa, które sankcjonowałoby wprowadzane porządki. 30 marca $1979 \mathrm{r}$. w referendum 98,2 proc. głosujących opowiedziało się za ustanowieniem Islamskiej Republiki Iranu ${ }^{45}$. Konstytucja nowej republiki (proklamowanej już 1 kwietnia) głosiła, że: Wszystkie prawa i przepisy cywilne, karne, finansowe, ekonomiczne, administracyjne, kulturalne, wojskowe, polityczne oraz inne musza być wzorowane na nakazach islamu ${ }^{46}$. Mroczny obraz nowego Iranu i narastającą atmosferę osaczenia sygnalizuje w Persepolis sekwencja złożona z ujęć o wyraźnej dominancie czerni. W ciemnościach rozlega się komunikat radiowy ogłaszający wynik wyborów i podkreślający demokratyczny charakter głosowania oraz jednomyślność narodu. W kolejnych odsłonach na czarnym tle $\mathrm{w}$ diafragmie irysowej pojawiają się członkowie rodziny Marji komentujący sytuację. Mama informuje o emigracji przyjaciół, którzy uznali, że w kraju zrobiło się niebezpiecznie. Ojciec szepcze o znajomym utopionym w wannie. Babcia mówi do telefonu: Siamak uciekt wraz z rodzina, ci dranie zabili mu siostrę. Pełen optymizmu stryj Anusz uspokaja rodzinę: To normalne. Każda rewolucja ma okres przesilenia. Połowa kraju jest niepiśmienna. Naród może zjednoczyć tylko nacjonalizm i religia.

Rodzinne wiadomości - pełne niepokoju osobiste świadectwa relacjonujące strategię nowego reżimu - zostają zestawione $\mathrm{z}$ oficjalnym przekazem medialnym. $\mathrm{Z}$ czarnego tła wyłania się ekran telewizora, z którego brodaty mężczyzna oznajmia: Oczyścimy kraj z elementów antyrewolucyjnych. Zapanuje jedno prawo - prawo krwi. Za „element antyrewolucyjny” zostaje uznany stryj Anusz, do końca głęboko wierzący w słuszność marksistowskich ideałów. Marji odwiedza go przed śmiercią w więziennej celi. Łącząca ich więź oraz przejmująca scena ostatniego pożegnania sprawiają, że Anusz nie jest jednym z setek straconych anonimowych komunistów. Ma własną twarz i historię, która przekonująco wyjaśnia polityczne zaangażowanie i życiowe wybory. Jego tragiczny los pozwala zrozumieć ideową złożoność ruchu rewolucyjnego oraz adaptowanie marksizmu do warunków lokalnych. Temat ten podejmuje również Bojkot (Bājkut, 1986) Mohsena Machmalbafa - jego trzeci film fabularny, jawnie polityczny i zgodny z linią reżimu Chomeiniego. Bohaterem Bojkotu, którego akcja rozgrywa się przed rewolucją, jest komunista Wale, członek partii Tude (w tej roli przyszły reżyser Madżid Madżidi). Za swoją działalność zostaje osadzony wraz z innymi więźniami politycznymi - w tym członkami bojówek islamskich. Pod ich wpływem Wale zaczyna wątpić w wyznawaną ideologię. Ostatecznie, na krótko przed egzekucją, zrozpaczony rezygnuje ze swoich przekonań i umiera w poczuciu przegranej ${ }^{47}$. Bojkot, ukazujący ludzki wymiar walki ideologicznej oraz jej konsekwencje dla życia prywatnego obu stron konfliktu ${ }^{48}$, pozostaje jednak filmem-narzędziem służącym represyjnej propagandzie. Istnieją świadectwa byłych lewicowych więźniów politycznych, którzy w celach resocjalizacyjnych byli zmuszani do wielokrotnego oglądania filmu Machmalbafa 49.

Szyickie duchowieństwo, za czasów Pahlawich zepchnięte na margines życia społeczno-kulturalnego, w 1979 r. przejęło ster kierowania państwem. Jakie warunki historyczne stworzyły ulemom okazję, by wykorzystać religię do porwania tłumów? Sojusz szyickich mudżahedinów ${ }^{50}$ oraz programowo ateistycznych ko- 
munistów dowodzi, że wykorzystanie islamu do aktywizacji społeczeństwa nie jest równoznaczne z jego religijnością. Jednakże język religii był dla większości Irańczyków głównym systemem poznawczym i komunikacyjnym, więc jego użycie dawało liderom możliwość kierowania thumem ${ }^{51}$. W retoryce tej islam przestał być tylko religią, a stał się symbolem protestu mobilizującym do walki o ideały ,islamskiej rewolucji”. Jak to skomentował Arjomand: Zamieńcie słowo „, socjalizm” stowem „islam”, a „, strajk generalny” - „rewolucja przeciw tyranii” i zrozumiecie, skąd ptynęła efektywność masowego wystapienia Irańczyków, które trwało 5 miesięcy i położyło kres monarchii liczacej sobie 2,5 tysiąca lat ${ }^{52}$.

Nowe władze, aby rozszerzyć rewolucję islamską na sąsiedni Irak, zaczęły podburzać tamtejszych szyitów przeciwko rządowi. W odpowiedzi Saddam Husajn w 1980 r. zaatakował osłabiony czystkami we własnej armii Iran ${ }^{53}$. Iracki dyktator spodziewał się szybkiego zwycięstwa, jednak wojna przeciągnęła się do $1988 \mathrm{r}$. i pochłonęła ok. miliona ofiar ${ }^{54}$. W Persepolis lata wojny i porewolucyjnego terroru oglądamy z perspektywy dorastającej Marjane: Nowy rząd wprowadził jeszcze surowsze prawa. Po dwóch latach każdy aspekt naszego życia uległ zmianie. My także. Jej słowom towarzyszy wiele mówiący obraz - postacie zebranych uczennic w mundurkach zgodnych z zasadą hidżabu ${ }^{55}$ zlewają się w czarną masę. Dopiero przyglądając się ich twarzom, można dostrzec indywidualność każdej z nich. Zunifikowany ubiór odzwierciedla wymogi, jakie zaczęły obowiązywać w przestrzeni publicznej. W marcu 1979 r. Chomeini wprowadził rozkazem kontrolę przestrzegania muzułmańskiego kanonu ubierania się kobiet w miejscach publicznych ${ }^{56}$. Przez instytucjonalizację prawa szariatu tradycyjna praktyka, która przez stulecia należała do sfery obyczaju, stała się oficjalnym nakazem obowiązującym Iranki już od dziewiątego roku życia. Z perspektywy islamu to właśnie hidżab daje kobietom możliwość aktywności bez skrępowania, zapewnia im anonimowość i pozwala działać bez narażenia na nieodpowiednie traktowanie. W Islamskiej Republice Iranu jest to jednak nakaz, którego ignorowanie w miejscach publicznych grozi karą 74 batów ${ }^{57}$. W Persepolis możemy zaobserwować różne formy respektowania zasady hidżabu. Zwolenniczki teokratycznego reżimu noszą czador - płaszcz bez rękawów zakrywający postać od głowy do stóp i maskujący wszelkie wypukłości sylwetki ${ }^{58}$. Mniej konserwatywną formą jest połączenie luźnej tuniki (mānto) i chusty (rusari) lub maghna 'eh - nakrycia głowy z otworem na twarz zasłaniającego szyję i ramiona. Taki strój nosi Marjane, kobiety z jej rodziny oraz większość koleżanek.

Persepolis nie wyszczególnia wszystkich zmian, jakie wprowadziły nowe władze. Chomeini powołał do życia Islamską Partię Republikańską, której hasłem było Jedna wspólnota, jedna religia, jeden porzadek, jeden przywódca ${ }^{59} . \mathrm{W}$ imię nowych pryncypiów wyraźnie ograniczono prawa kobiet (wyznaczając listę zawodów, w których mogą pracować), zakazano importu alkoholu i wieprzowiny, ocenzurowano zachodnie filmy, wprowadzono zakaz słuchania muzyki pop i publicznie palono niewygodne książki, a dysydentów poddawano pokazowym procesom. Wszystko to wywołało protesty intelektualistów i studentów, środowisk o orientacji tradycyjnie liberalnej lub lewicowej. Reakcją Chomeiniego było zamknięcie w 1980 r. uniwersytetów na dwa lata.

Przestrzeń publiczna w Iranie lat 80. została zdominowana również przez kult męczennictwa. Wiązał się on z retoryką Chomeiniego, która wzywała do szahadatu - męczeńskiej śmierci jako świadectwa wiary ${ }^{60}$ - i opierała się na teleologicznym 
rozumieniu historii. Rewolucja miała oczyścić Iran z obcych wpływów i zaprowadzić porządek społeczny w harmonii z boskim prawem ${ }^{61}$. Służyła temu wojenna machina propagandowa, zaangażowana w kreowanie obrazu męczennika - szahida ${ }^{62}$ - jako koniecznej ofiary w dążeniu do doskonałości. Chociaż idea męczeństwa nie była nowa w kulturze perskiej, w pierwszych latach Islamskiej Republiki Iranu stała się „,zawołaniem bojowym”, odzwierciedlając specyficznie rozumiany patriotyzm. Ci, którzy polegli w walce z szachem lub irackimi wojskami, osiągali status męczenników. O powadze, z jaką nowy reżim traktował ich etos, świadczą kontrowersje związane z recepcją filmu Iradża Ghaderiego $W$ czyśćcu (Barzachihā, 1980/1982), którego fabuła na bieżąco komentowała inwazję Iraku. Grupa więźniów - kryminalistów i współpracowników SAWAK-u - zostaje w rewolucyjnej zawierusze wypuszczona na wolność. Mężczyźni chcą uciec z kraju, jednak wobec zbliżających się wojsk Husajna decydują się zostać, by bronić lokalnej społeczności, i giną w walce jako męczennicy. $W$ czyśćcu ukazywał potrzebę zjednoczenia się Irańczyków przeciwko wspólnemu wrogowi: oto poplecznicy poprzedniego reżimu porzucają zamiar ucieczki i stają do walki w obronie ojczyzny. Rozliczeniowy film Ghaderiego nie spotkał się z aprobatą agresywnej i rewizjonistycznej polityki kulturalnej Chomeiniego. Reżyser został oskarżony o bezczeszczenie krwi męczenników i film zdjęto $z$ afisza ${ }^{63}$. Trafił na ekrany dopiero po 2 latach i stał się najbardziej dochodowym filmem irańskim. Warto dodać, że od lat 80. w Iranie istniał szczególny gatunek filmów wojennych - tzw. Kino Świętej Obrony, powstający przy logistycznej pomocy wojska i poniekąd na jego potrzeby. Filmy te, pełne przemocy i rewolucyjnych sloganów, pełniły funkcję ideologiczną: miały zachęcać do wstępowania w szeregi armii i walki z Irakiem, nazywanej przez władze Islamskiej Republiki „Świętą Obroną”. De facto strona irańska nie ograniczała się wyłącznie do działań obronnych. W 1982 r. ze strony Saddama Husajna padła propozycja pokoju. Została jednak odrzucona przez Chomeiniego, który miał nadzieję przenieść do Iraku zapoczątkowaną w Iranie rewolucję.

W Persepolis gloryfikację etosu męczeństwa wyrażają emitowane przez głośniki propagandowe komunikaty o sukcesach sił irańskich: Odwaga naszych żołnierzy daje owoce. Dziś nasza armia zniszczyła 63 irackie czotgi i 26 samolotów. Krew męczenników nawadnia nasza ziemię i daje nadzieje jałowej pustyni. Umierajacy męczennik wstrzykuje krew w żyły społeczeństwa. Perscy poeci, którzy za czasów Mohammada Rezy wzywali do walki o wolność i zrzucenia brzemienia despotyzmu, teraz oddali talenty na służbę rewolucji islamskiej, dokonując apoteozy idei szahadatu. Poezja lat 80. stworzyła paradygmat, który sięgał do pamięci kultury irańskiej (męczeńskiej śmierci szyickich proroków) i upatrywał sensu życia w świadectwie wiary oraz obrony ojczyzny przed obcą ingerencją ${ }^{64}$. Apologetką tej ideologii jest nauczycielka Marjane, która nakazuje zebranym na boisku uczennicom oddanie hołdu męczennikom, podczas gdy głos z megafonu obwieszcza: Wojna zabrała najlepsze dzieci tego kraju. Wkrótce z ich krwi narodzi się prawda. Za kogo umarli? Za nas! Nauczycielka przypomina wychowankom: Nasi żotnierze codziennie gina na granicy, broniąc naszego kraju przed niemoralnościa. Marjane kpi z tej patetycznej retoryki - w obecności koleżanek parodiuje rolę męczennicy, przewraca się na ziemię i symuluje agonię.

Ofiarność męczeńska Irańczyków stała się jednym z głównych filarów walki Chomeiniego z Irakiem, który nie zakładał takiej determinacji ze strony wroga. 
Nie każdy jednak ulegał tej perswazji. Pomoc domowa państwa Satrapi, pani Nassrin, jest zdruzgotana agitacją i psychomanipulacją przeprowadzaną w szkole. Pokazuje pracodawcom plastikowy kluczyk, który wręczano chłopcom w klasie jej czternastoletniego syna: Powiedzieli mu, że jeśli umrze w walce, otworzy nim bramy nieba. Mówili, że w niebie jest dużo jedzenia, kobiet, złotych domów i brylantów. (...) Wychowałam piątke dzieci, a teraz chca mi dać za najstarszego plastikowy klucz! Słowa prostej kobiety obnażają manipulację władz wojskowych, które wysyłają nastolatków na pewną śmierć, oczyszczając nimi pola minowe ${ }^{65}$.

Najdłuższy w historii XX w. konflikt militarny jest w Persepolis ukazany przez pryzmat egzystencji ludności cywilnej i życia prywatnego bohaterki. Salwy armat i świst przelatujących nad głowami bombowców przeplatają się z dźwiękami heavymetalowej muzyki słuchanej przez nastolatkę w zaciszu pokoju. Pewnego dnia rakieta spada na ulicę, gdzie mieszka rodzina Satrapi. Marjane, przechodząc obok zrujnowanego domu sąsiadów, z przerażeniem zauważa wystającą z gruzów dziewczęcą rękę z bransoletką - metonimię tragedii wojny. Odnosząc się do tej sceny, autorka daje prawdzie emocji pierwszeństwo przed kronikarską ilustracją faktów: To się zdarzyło naprawdę, ale dopiero kiedy wróciłam do swojego kraju z Wiednia. Nie miałam wtedy 14 lat, tylko 18. Dla potrzeb narracyjnych zmieniłam kolejność, ale co to zmienia w rzeczywistości? Czy się ma 14 czy 18 lat, kiedy spada bomba w sąsiedztwie i umiera ktoś, kto jest przyjacielem, prawda emocji pozostaje ta sama ${ }^{66}$.

Chociaż ewakuacje do schronów stają się codziennością, mieszkańcy Teheranu starają się wieść normalne życie - dzieci chodzą do szkoły, dorośli pracują, a w wolnych chwilach urządzają sekretne przyjęcia z nielegalnie produkowanym alkoholem. Jak zauważył Tadeusz Sobolewski: Bohaterka wspomina Iran tak, jak ci, którzy przeżywali swoje dzieciństwo w ZSRR albo w stalinowskiej Polsce. Owszem, była to egzotyczna mieszanka absurdu i grozy, ale towarzyszyly jej nigdy nie zwalczone przyjemności życia. W teokratycznym Iranie, jak w komunizmie, panuje zbawienne dwójmyślenie: co innego obowiąuje publicznie, co innego $w$ domu ${ }^{67}$.

W kolejnej odsłonie Persepolis przenosimy się do Teheranu roku 1982. Podczas gdy odziana w czador nauczycielka oznajmia uczennicom, że chusta to oznaka wolności, a przyzwoita kobieta chroni się przed wzrokiem mężczyzn, jej podopieczne dyskretnie ekscytują się nowymi nabytkami muzycznymi - pod ławką krążą płyty zespołów Bee Gees i Abba. Marjane jest fanką Iron Maiden, album tej grupy kupuje na czarnym rynku, gdzie można znaleźć także inne zakazane towary - szminki, lakier do paznokci i karty do gry. Pomimo kontroli w sferze publicznej oraz propagowania muzułmańskich ideałów kobiecości nastoletnia Marjane na swój sposób manifestuje młodzieńczy bunt. Jego wyrazem jest kurtka z własnoręcznie zrobionym napisem Punk is not ded (pisownia oryginalna). Kontrowersyjne hasło, buty z logo Nike i zsuwająca się z włosów chusta bulwersują funkcjonariuszki żeńskiego patrolu policji obyczajowej. W scenie tej twórcy wydobywają ekspresyjne walory czadoru - spowite w jego fałdy strażniczki obyczajów przybierają niesamowite kształty, przypominając czarne zjawy wijące się wokół małej dziewczynki. Zauważają przypiętą do kurtki nastolatki plakietkę z Michaelem Jacksonem i zarzucają dziewczynie epatowanie „symbolem zachodniej dekadencji”. Ich komentarz jest zgodny z retoryką Chomeiniego, który ostrzegał rodaków, że wszelkie manifestacje westernizacji tlumia w irańskiej młodzieży ducha cnoty i bohaterstwa, rozpylaja truciznę i demoralizują umysły ${ }^{68}$. Wyrazem antyamerykań- 


\section{ELŻBIETA WIĄCEK}

skiej propagandy są w Persepolis widoczne na ulicach Teheranu murale - złowieszcza Statua Wolności z czaszką zamiast twarzy.

Źródeł tej dychotomicznej wizji świata można szukać w samym Koranie, opartym na paradygmacie binarnym, dzielącym świat na wiernych i niewiernych ${ }^{69}$ lub w koncepcjach Dżalala Al-e Ahmada, jednego z pierwszych oponentów modernizacji utożsamionej z westernizacją. Intelektualista i członek partii Tude opisał w pracy Qarbzadegi (wydanej w 1961 r.) ,okcydentozę”, czyli niszczący wpływ Zachodu na Iran. Aby unaocznić skutki bezrefleksyjnego przejęcia elementów obcej kultury, wykorzystał metaforę choroby, która niszczy organizm od środka, początkowo nie dając żadnych objawów ${ }^{70}$. Autor kreśli dwudzielną wizję świata, w którym na jednym biegunie są rozwinięte kraje Europy Zachodniej i USA, zaś na drugim - zacofane, biedne kraje Wschodu. Istoty zależności Irańczyków od Zachodu upatruje w tym, że mieszkańcy pierwszego świata produkują i sprzedają maszyny, a ci z drugiego jedynie je wykorzystują: Jedni to twórcy, drudzy konsumenci ${ }^{71}$. Za bierność wobec procesów kolonizacyjnych Al-e Ahmad wini przede wszystkim inteligencję, która uległa ślepej fascynacji Zachodem, zdradzając rodzime wartości. Remedium na „okcydentozę” ma być szyicki islam, który jako struktura spójna i totalna stanowi narzędzie do panowania nad społeczeństwem i kształtowania go wedle ugruntowanych zasad moralnych ${ }^{72}$. Prace Al-e Ahmada wzbudziły żywe zainteresowanie i stały się katalizatorem idei konserwatywnych w przeddzień islamskiej rewolucji.

Przewrót miał wpływ także na politykę zagraniczną Iranu. Hasło ajatollaha Ani Wschód, ani Zachód, tylko republika islamska zapowiadało dystansowanie się również od bloku sowieckiego. W Persepolis izolacja kraju po 1979 r. jest ukazana wyłącznie przez pryzmat życia prywatnego i kultury zubożonej przez drastyczną cenzurę. Jedynym oficjalnie dostępnym przekazem z zagranicy są japońskie filmy z Godzillą, wywołujące przerażenie Marji oraz irytację jej babci zdegustowanej miałkością fabuły. Izolacja kulturalna ma jednak mniej dotkliwe konsekwencje niż rygorystyczne ograniczenia $\mathrm{w}$ ruchu granicznym. Wujek bohaterki, Taher, musi szybko przejść operację na otwartym sercu, która jest możliwa tylko w Anglii. Przy zamkniętych granicach z kraju mogą wyjechać tylko bardzo chorzy. Żona Tahera usiłuje przekonać dyrektora szpitala o konieczności wyjazdu męża. Ku jej zaskoczeniu stanowisko to piastuje mężczyzna, który niedawno mył u niej okna. Nowy dyrektor, całkowicie niekompetentny w dziedzinie medycyny, bagatelizuje stan zdrowia umierającego pacjenta, na każde pytanie odpowiadając: Jeśli Bóg da. Kobieta jest załamana mentalną przepaścią między nią a rozmówcą i brakiem perspektyw na ocalenie męża, a zarazem pełna gniewu na absurd społecznych przemian: Każdy pomywacz okien, jeśli tylko ma brodę i garnitur, może teraz kierować szpitalem. Państwo Satrapi próbują pomoc Taherowi, kontaktując się ze znajomym fałszerzem paszportów. Nadziei na pozytywne rozwiązanie sprawy kładzie kres interwencja policji opierającej się na systemie sąsiedzkich donosów. Tajna pracownia zostaje odkryta i zdemolowana. Fałszerz ucieka do Turcji, a potem do Szwecji, zaś jego współpracowniczka, komunistka, zostaje stracona.

Zbuntowana Marjane nie wpisuje się w porewolucyjny ideał pobożnej, skromnej muzułmanki, co przysparza kolejnych problemów rodzinie oraz jej samej. Bezkompromisowa nastolatka nie może znieść hipokryzji propagandy w szkole. Kiedy nauczycielka oznajmia z zadowoleniem, że: Dzięki naszemu no- 

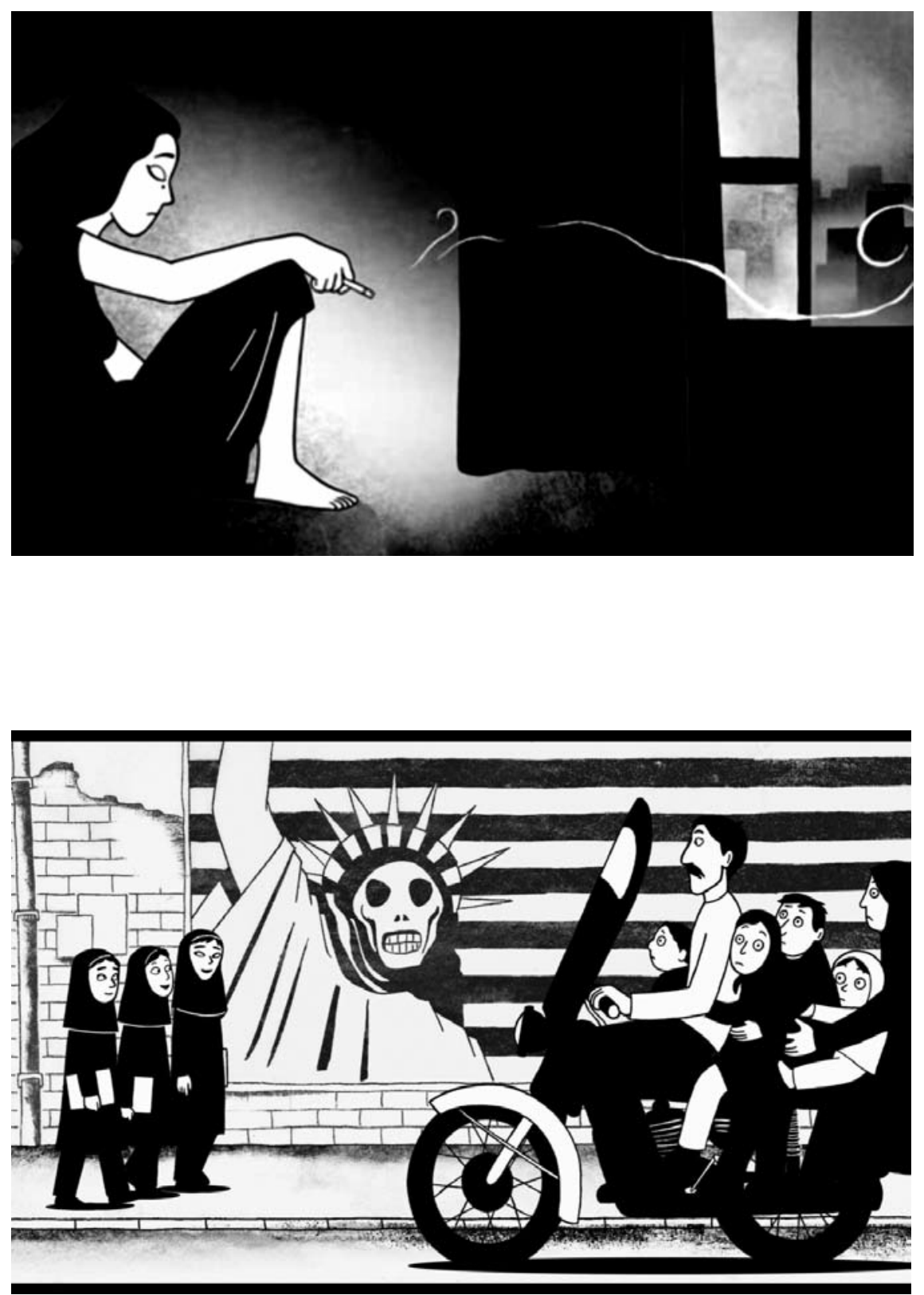

Persepolis, reż. Marjane Satrapi, Vincent Paronnaud (2007) 


\section{ELŻBIETA WIĄCEK}

wemu rządowi nie mamy już więźniów politycznych, bohaterka zarzuca jej kłamstwo, wywołując aplauz całej klasy (Szach więzit mojego wujka, a nowy reżim go rozstrzelat. Za szacha byto 3 tysiące więźniów, teraz jest ich 30 tysięcy!). Akty niesubordynacji się powtarzają, więc dyrektorka szkoły informuje rodziców Marjane. Jednocześnie represje w kraju wzmagają się, a konflikt z Irakiem przybiera na sile. W trosce o bezpieczeństwo córki rodzice decydują się wysłać Marjane do Wiednia. Tam jednak dziewczyna musi borykać się z nowymi problemami. Jako Iranka nie jest akceptowana przez rówieśników, zrozumienie znajduje jedynie w grupie społecznych outsiderów o poglądach anarchistycznych, od których uczy się nonszalancji i nihilizmu. Narracja bohaterki obnaża bezideowość zachodnich ruchów kontestacyjnych: rząd mógł być spokojny, bo ci anarchiści głównie pili piwo i jedli kiełbaski. W zestawieniu z dramatycznymi doświadczeniami irańskiej koleżanki przedstawiciele europejskich subkultur wypadają wyjątkowo niedojrzale: są bezpieczni i wolni, ale nie umieją właściwie korzystać z wolności. Uprzedzenia, z jakimi styka się bohaterka $\mathrm{z}$ racji swojego pochodzenia, prowadzą do kryzysu tożsamości, załamania psychicznego i bezdomności. Zdesperowana, w $1992 \mathrm{r}$. wraca do ojczyzny.

Iran początku lat 90. jest zrujnowany bezsensowną wojną. Jak konkluduje ojciec bohaterki: Zachód sprzedawat broń obu stronom, a my braliśmy udział $w$ tej cynicznej grze. Milion ofiar na nic. Spacer po Teheranie przypomina Marjane spacer po cmentarzu - nowe nazwy ulic i martyrologiczne murale gloryfikują pamięć szahidów. Przestrzeń publiczną i oficjalny dyskurs przenika kult męczenników. W obowiązkowych pogadankach na uniwersytecie nawet nakaz skromnego stroju wymaganego od studentek uzasadnia się szacunkiem do poległych w rewolucji i na wojnie. Marjane zwraca uwagę na niesprawiedliwy brak proporcji w oczekiwaniach wobec obu płci. Przepisy związane z zasadą hidżabu dotyczą tylko kobiet, tymczasem mężczyźni mogą nosić różne stroje i fryzury: Ich obcisłe spodnie maja na mnie nie oddziaływać, podczas gdy oni podniecaja się mniejsza chusta? Rygorystyczne zakazy tabuizujące kobiece ciało sprawiają, że ćwiczenia rysunkowe $\mathrm{z}$ anatomii przybierają absurdalną postać - modelka w czadorze ze wszystkich stron wygląda niemal identycznie. Reprodukcje obrazów Sandro Botticellego omawiane na zajęciach z historii sztuki są parodią oryginałów - zgodnie z wymogami cenzury kobiecy akt w Narodzinach Wenus jest w całości zamazany czarnym flamastrem.

Gęstniejąca sieć ograniczeń dotyka bohaterkę również w sferze życia osobistego. Zakochana Marjane nie może swobodnie spotykać się z chłopakiem, gdyż strażnicy rewolucji inwigilują spacerujące pary i sprawdzają stopień ich pokrewieństwa. Jedyną alternatywą są klaustrofobiczne randki w domu lub wzięcie ślubu. Braku wolności nie jest w stanie zrównoważyć nawet wsparcie kochających rodziców i babci. Śmiertelny wypadek przyjaciela uciekającego przed policją obyczajową i porażka zawartego zbyt pośpiesznie małżeństwa skłaniają bohaterkę do trudnej decyzji o ponownej emigracji, tym razem do Francji. Na tym etapie kończy się filmowa historia.

Wymowa Persepolis - krytyczna wobec tego, jaki obrót przybrała rewolucja wywołała oburzenie władz Iranu jeszcze przed światową premierą w 2007 r. na festiwalu w Cannes, gdzie film został wyróżniony Nagrodą Jury. Rząd irański protestował przeciwko pokazowi, nazywając go „aktem antykulturalnym i politycznym". Mehdi Hallor, doradca rządu irańskiego ds. kinematografii związany z filmową Fundacją Farabi, wysłał list do ambasady francuskiej w Teheranie, 
w którym oskarżył film o propagowanie nieprawdziwego oblicza dokonań rewolucji: Islamofobia w zachodnim kinie rozpoczęła się we Francji, a wyprodukowanie $i$ nagrodzenie antyirańskiego filmu $w$ Cannes potwierdza ten stan rzeczy ${ }^{73}$. W konsekwencji dystrybucja Persepolis została w Iranie zakazana. W lutym 2008 r. zezwolono na kilka pokazów filmu w kinach w Teheranie, ale w ocenzurowanej wersji. Naciski władz nie odniosły większego skutku na arenie międzynarodowej: film został wycofany jedynie z udziału w MFF w Bangkoku i - początkowo - zakazany w Libanie, ponieważ kilku wpływowych duchownych uznało film za $o b$ raźliwy $w$ stosunku do Iranu $i$ do islamu (zakaz zniesiono po protestach intelektualistów libańskich) ${ }^{74}$. Oficjalne stanowisko rządu irańskiego kontrastowało z entuzjastycznym przyjęciem Persepolis przez krytyków i publiczność na całym świecie. Akademia Sztuki i Techniki Filmowej uhonorowała film dwiema statuetkami Cezara za reżyserię i najlepszy scenariusz adaptowany, zaś Stowarzyszenie Nowojorskich Krytyków Filmowych przyznało mu nagrodę za najlepszy film animowany w 2007 r. W 2008 r. Persepolis został nominowany do Oscara jako długometrażowy film animowany, ale przegrał $\mathrm{z}$ amerykańską animacją komputerową Ratatouille wyprodukowaną przez Pixar.

Paradoksem wydaje się, że tytułowe „Persepolis” (grecka nazwa Pārsy) - starożytnego miasta, które w czasach dynastii Achemenidów ${ }^{75}$ pełniło funkcję ceremonialnej stolicy imperium perskiego - jest w filmie praktycznie nieobecne, mimo że do dziś jego ruiny znajdują się na terenie Iranu. Jaką zatem funkcję pełni tytuł w kontekście opowiedzianej historii? Odpowiedzi można szukać w słowach babci Marjane, która przed wyjazdem wnuczki za granicę przypomina jej: Nigdy nie zapominaj o tym, skad pochodzisz ${ }^{76}$. Miejsca pochodzenia Satrapi nie utożsamia z Iranem porewolucyjnym - jej ojczyzna to wielopoziomowa kultura, a obecne realia republiki muzułmańskiej są tylko bardzo cienką jej warstwą. Już ponad dwa i pół tysiąca lat temu Persja była kolebką cywilizacji. Kiedy w Europie dopiero tworzyły się zręby państwowości, była ośrodkiem rozwoju wielu dziedzin wiedzy i sztuk. Używając nazwy „Persepolis”, Satrapi apeluje, by nie postrzegać jej ojczyzny jedynie przez pryzmat współczesności: Od czasów islamskiej rewolucji o tej starożytnej wspaniałej cywilizacji mówi się głównie w związku z fundamentalizmem, fanatyzmem i terroryzmem. Jako Iranka wiem, że ten obraz jest daleki od prawdy. Nie powinno się oceniać całego narodu przez pryzmat wypaczeń grupy ekstremistów ${ }^{77}$. Na przykładzie własnej biografii, zdeterminowanej transformacją ustrojową, Satrapi ukazuje, jak totalna islamizacja, zaprowadzona w kulturze irańskiej z początkiem lat 80. XX w., doprowadziła do przewartościowań. Jak zauważa Haddad Adel, w aktualnych podręcznikach szkolnych Iran określany jest jako „Iran islamski”, a starożytnej Persji nie opisuje się już jako raju utraconego Irańczyków, lecz podkreśla się jego moralne zepsucie ${ }^{78}$. Islam stał się dominantą kulturową, podstawą koncepcji człowieka, społeczeństwa i państwa. Wartości, ukształtowane na długo przed ekspansją arabską oraz islamizacją: w antycznych imperiach perskich oraz w okresie hellenistycznym ${ }^{79}$, w którym przenikały się silnie kultury Wschodu i Zachodu, straciły rangę paradygmatu. Persepolis odwołuje się do tych dawnych wzorców kulturowych nie wprost, lecz przez aluzje w dialogach oraz formę graficzną. Opowieść wujka Anusza nawiązuje do stylu dawnych miniatur perskich - tłem wydarzeń są pałace, ogrody i egzotyczne pejzaże ukazane w charakterystycznej wielocentrycznej perspektywie. 
W wyniku transformacji w Iranie monizm religijno-polityczny stanowiący fundament nowego reżimu ukształtował nowego człowieka - homo islamicus. Nie chodzi tu po prostu o muzułmanina, ale człowieka, który kieruje się islamem jako myślą przewodnią w każdej dziedzinie życia ${ }^{80}$. W warstwie audiowizualnej egzemplifikacją projektu homo islamicus były m.in. wczesne filmy Machmalbafa: Dwoje niewidzacych oczu (Do czeszme bi su, 1983) i Esteaze (Este'aze, 1983), od których reżyser po latach się odciął. Oficjalna dominacja homo islamicus doprowadziła do powstania w Iranie systemu, który nosi znamiona totalitarnego. Nie wszyscy Irańczycy pogodzili się z kierunkiem tej zmiany i wybrali emigrację wewnętrzną lub zagraniczną. W efekcie w zbiorowym portrecie społeczeństwa irańskiego narysowanym w Persepolis szczególną uwagę zwraca pogłębiająca się przepaść między sferą prywatną i publiczną. Podział ten cechuje życie jednostek w każdym społeczeństwie, lecz w porewolucyjnym Iranie, gdzie aparat państwowy sprawuje nad życiem społecznym wyjątkowo rygorystyczną kontrolę, te dwa aspekty rozchodzą się bardzo daleko. Podczas gdy na uniwersytecie w Teheranie wykłady z historii sztuki są ilustrowane ocenzurowanymi reprodukcjami Botticellego, studentki w sekrecie przeglądają magazyn „Vogue”.

Persepolis może nie spełnić oczekiwań tych, którzy spodziewają się realistycznego obrazu sytuacji politycznej; otrzymują bowiem jedynie subiektywny zarys wydarzeń oglądany oczami dziecka, a potem dorastającej dziewczyny. Zaskakiwać może, że w opowieści tej nigdy nie pojawia się Chomeini, uznawany za twarz irańskiej rewolucji. W zamian pojawia się paradoksalny duet - Bóg i Karol Marks, z którymi bohaterka prowadzi rozmowy o sensie życia. Dzięki osobistej narracji rewolucja i wojna $\mathrm{z}$ Irakiem przestają być historycznymi wydarzeniami z dalekiego kraju. Francuski historyk Pierre Nora, pisząc o różnicach między pamięcią i historią, zauważa, że pamięć nieustannie ewoluuje, jest afektywna i magiczna; przyswaja zatem jedynie pasujace do niej fakty; karmi wspomnienia, które moga być nieostre lub odległe, globalne lub oderwane, partykularne lub symboliczne ${ }^{81}$. $\mathrm{Z}$ drugiej strony historia należy do wszystkich i do nikogo, dlatego rości sobie pretensje do ponadczasowego autorytetu - jest wytworem intelektualnym i świeckim, domaga się więc analizy i krytyki. Nora stwierdza, że pamięć jest fenomenem wiecznie aktualnym, to więź łącząca człowieka z wieczną teraźniejszością; historia stanowi natomiast reprezentację przeszłości - jest zawsze problematyczną i niepełną rekonstrukcją tego, czego już nie ma ${ }^{82}$. Chociaż Satrapi deklaruje, że „Persepolis" nie jest tylko (...) prywatna opowieścia, to historia uniwersalna, która trzeba było opowiedzieć ${ }^{83}$, jej narracja ma cechy, które Nora przypisuje pamięci umieszcza wspomnienie w porządku sakralnym, czego przejawem są rozmowy bohaterki z Bogiem na temat ludzkich poczynań.

Aktualność i uniwersalność Persepolis potwierdziły dramatyczne wydarzenia w Islamskiej Republice Iranu, jakie miały miejsce po wyborach w 2009 r. zakończonych zwycięstwem na drugą kadencję ówczesnego prezydenta Mahmuda Ahmadineżada. W konsekwencji podejrzeń o ich sfałszowanie w kraju wybuchły zamieszki, które zostały krwawo stłumione. Władze Iranu zablokowały możliwość wysyłania SMS-ów, ograniczyły wykonywanie lokalnych połączeń telefonicznych, uniemożliwiły odbiór zagranicznej telewizji i zakazały zagranicznym dziennikarzom rejestrowania protestów. Zwolennicy opozycji wykorzystali Internet jako narzędzie komunikacji. Dwójka emigrantów o pseudonimach Payman i Sina 
stworzyła rysunkową interpretację wydarzeń pt. Persepolis 2.0., używając - za zgodą Satrapi - kadrów z komiksu opatrzonych nowym komentarzem. Komiks umieszczony na stronie www.spreadpersepolis.com spotkał się z ogromnym odzewem użytkowników ze 120 krajów zainteresowanych wsparciem dla protestujących. Fakt, że rysunkowe sceny idealnie pasują do sytuacji z 2009 r. mimo, że opisane w nich wydarzenia rozegrały się 30 lat wcześniej, jest niezwykle wymowny: mechanizm represji w Iranie nie uległ większym zmianom.

ELŻBIETA WIĄCEK

${ }^{1} \mathrm{~S}$. Jalili, Iran marks 40th anniversary of Islamic Revolution, https://www.aljazeera.com/news/2019/02/millions-mark-40th-anniversaryiranian-revolution-190211002413307.html (dostęp: 30.03.2019).

${ }^{2}$ W czasach Kadżarów semantyka słowa doulat - „państwo" - obejmowała elitę rządzącą: szacha, urzędników na służbie państwowej i przywódców klanów. M. Abassy, Kultura wobec postępu i modernizacji. Rosja $i$ Iran $w$ perspektywie porównawczej, Wydawnictwo Uniwersytetu Jagiellońskiego, Kraków 2013, s. 419.

${ }^{3}$ Tamże, s. 420.

${ }^{4}$ Tamże.

${ }^{5}$ Polskie wydanie z 2006 r. składa się z dwóch tomów: Persepolis 1: Historia dzieciństwa i Persepolis 2: Historia powrotu.

${ }^{6} \mathrm{M}$. Satrapi, How to film a graphic novel?, „The Guardian” 10.02.2016, https:/www.theguardian.com/film/2011/jun/16/how-to-film-agraphic-novel (dostęp: 7.04.2019).

${ }^{7}$ Autorka otrzymała nagrodę Angoulême Coup de Coeur Award.

8 „Islamska Republika Iranu” to bezpośrednie thumaczenie nazwy państwa irańskiego z języka perskiego (pers. Dżomhuri-je Eslāmi-je Irān) stosowane w dyplomacji oraz publikacjach. Niektórzy iraniści skłaniają się jednak do używania formy „muzułmańska”, pamiętając, że w języku polskim przymiotnik od „islamu” to „muzułmański”, a nie ,islamski”, który niesie ze sobą inne znaczenie. Jak np. zauważa Małgorzata Stolarczyk, islamski to ten, który zajmuje się islamem, jak badacz islamu czy islamista. Por. M. Stolarczyk, Iran - państwo i religia, Wydawnictwo Akademickie Dialog, Warszawa 2001, s. 7.

${ }^{9}$ S. Hattenstone, Confessions of Miss Mischief, „The Guardian” 7.11.2012, https://www.theguardian.com/film/2008/mar/29/biography (dostęp: 7.04.2019).
${ }^{10}$ Tworzy często pod pseudonimem Winshluss. ${ }^{11}$ Pressbook filmu Persepolis, Gutek Film 2008, http://gutekfilm.pl/wp-content/uploads/sites/2/2015/03/Persepolis-pressbook.pdf (dostęp: 5.04.2019).

12 J. Hetherington, „Persepolis” in Motion, https://www.awn.com/animationworld/persepolis-motion (dostęp: 7.04.2019).

${ }^{13}$ Tamże.

${ }^{14}$ I. Grelowska, Marjane Satrapi-mistrzyni komiksu dla dorostych, https://kobieta.interia.pl/gwiazdy/news-marjane-satrapi-mistrzyni-komiksu-dla-doroslych,nId,4123-09\#utm_source $=$ paste $\& u$ tm_medium $=$ paste $\& u$ tm campaign=chrome (dostęp: 9.04.2019).

${ }^{15}$ N. R. Keddie, Współczesny Iran. Źródła i konsekwencje rewolucji, Wydawnictwo Uniwersytetu Jagiellońskiego, Kraków 2007, s. 69-81.

${ }^{16}$ Niezależna polityka demokratycznie wybranego premiera Iranu Mohammada Mossadegha stała się przyczyną nacisków politycznych na szacha ze strony CIA, aby ten odwołał premiera. Kiedy Mossadegh odmówił ustąpienia z urzędu, w 1953 r. CIA zorganizowała w Teheranie demonstrację poparcia dla szacha, w wyniku której doszło do zamieszek, obalenia rządu i przejęcia przez szacha pełnej władzy w państwie. Pahlawi poparł pucz po otrzymaniu dużych łapówek z rąk agentów wywiadu Stanów Zjednoczonych. Zob. S. Kinzer, All the Shah's Men. An American Coup and the Roots of Middle East Terror, John Wiley and Sons, New York 2003, s. 7.

${ }^{17}$ Por. M. Abassy, dz. cyt., s. 452.

${ }^{18}$ Tamże.

${ }^{19}$ R. Kapuściński, Szachinszach, Wydawnictwo Literackie, Warszawa 2007, s. 32.

${ }^{20}$ A. Krasnowolska, Teatr irański, w: Teatr Orientu - materiaty z sesji naukowej, red. i wstęp P. Piekarski, Wydawnictwo Medycyna Praktyczna, Kraków 1998, s. 59-60.

${ }^{21}$ Pressbook filmu, dz. cyt. 


\section{ELŻBIETA WIĄCEK}

${ }^{22}$ A. Gheissari, Iranian Intellectuals in the 20th Century, University of Texas Press, Austin 1998, s. 64-69.

${ }^{23}$ S. Hunter, Iran Divided. The Historical Roots of Iranian Debates on Identity, Culture and Governance in the Twenty-First Century, Rowman \& Littlefield, London 2014, s. 66-68.

${ }^{24}$ Brał aktywny udział w irańskiej rewolucji konstytucyjnej (1905-1911). W latach 20. XX w. przewodził utworzonej przez siebie Partii Socjalistycznej. Zob. M. Behrooz, Rebels with a Cause: The Failure of the Left in Iran, I. B. Tauris, London 2000, s. 4.

${ }^{25}$ E. Abrahamian, Historia wspótczesnego Iranu, thum. N. Nowak, Wydawnictwo Naukowe PWN, Warszawa 2009, s. 151-151.

${ }^{26}$ Historia Iranu, red. J. Hauziński, A. Krasnowolska i inni, Ossolineum, Wrocław 2010, s. $853-854$.

${ }^{27}$ E. Abrahamian, dz. cyt., s. 160.

${ }^{28}$ J. Dul, Rewolucja Chomeiniego, Młodzieżowa Agencja Wydawnicza, Warszawa 1990, s. 15.

${ }^{29}$ Zob. tamże, s. 27.

${ }^{30}$ M. Kamrava, The Modern Middle East: A Political History Since the First World War, University of California Press, Berkeley - Los Angeles - London 2011, s. 148.

${ }^{31}$ E. Abrahamian, Tortured Confessions, University of California Press, Berkeley 1999, s. 84-90 .

32 SAWAK (Narodowa Organizacja Wywiadu i Bezpieczeństwa) został utworzony w $1957 \mathrm{r}$.

${ }^{33}$ J. Amuzegar, Dynamics of the Iranian Revolution: The Pahlavis' Triumph and Tragedy, SUNY Press, Albany 1991, s. 109.

${ }^{34}$ Zob. R. Czulda, Savak: irańskie Gestapo, „Uważam Rze Historia” 23.02.2014, nr 2, s. $32-35$.

${ }^{35} \mathrm{https}: / /$ www.youtube.com/watch? $\mathrm{v}=\mathrm{StSgO} \_-$ OUcE (dostęp: 2.05.2019).

${ }^{36}$ H. Chehabi, Iranian Politics and Religious Modernism: the liberation movement of Iran under the Shah and Khomeini, Cornell University Press, Ithaca N.Y. 1990, s. 8.

${ }^{37}$ M. Abassy, Eminent Persians, Syracuse University Press, Syracuse N.Y 2008, s. 308-310.

${ }^{38}$ Po przejęciu władzy w Iranie przez fundamentalistów islamskich kwatera główna SAWAK-u została wzięta szturmem, a wielu oficerów osądzono i stracono.G. R. Afkhami, Life and Times of the Shah, University of California Press, Berkeley 2009, s. 386.

${ }^{39}$ Ustanowienie dynastii Safawidów jest często uważane za początek nowożytnej historii Iranu, a stworzone przez nich państwo za oznakę formowania się perskiego państwa narodowego.
${ }^{40}$ M. Abassy, dz. cyt., s. 420.

${ }^{41} \mathrm{~S}$. Arjomand, The Turban for the Crown. The Islamic Revolution in Iran, Oxford University Press, New York - Oxford 1988, s. 23.

${ }^{42}$ Szerzej na temat politycznych i społecznych uwarunkowań władzy zob. A. Amanat, Pivot of the Universe. Nasir al-Din Shah Qajar and the Iranian Monarchy 1831-1896, London New York 1997, s. 225-237.

${ }^{43}$ Ostatecznym testem była zdolność do zdobycia i utrzymania rządów. Zob. H. Katouzian, Riza Shah's political legitimacy and social base 1921-1941, w: The Making of Modern Iran. State and Society under Riza Shah, 1921-1941, red. S. Cronin, Routledge, London 2003, s. 17.

${ }^{44}$ E. Abrahamian, Historia współczesnego Iranu, dz. cyt., s. 213.

${ }^{45}$ Rewolucja islamska w Iranie, w: Oxford Wielka Historia Świata, t. 29: XX wiek. Świat i Polska po II wojnie światowej - Dekolonizacja - Lata siedemdziesiate - Filozofia, Poznań, s. 150-157.

${ }^{46}$ E. Abrahamian, Historia wspótczesnego Iranu, dz. cyt., s. 213.

${ }^{47}$ E. Wiącek, M. Kucharczyk, Kino irańskie we władzy ajatollahów, w: Historia kina tom 4. Kino końca wieku, red. T. Lubelski, I. Sowińska, R. Syska, Universitas, Kraków 2019, s. 652 .

${ }^{48}$ Zob. E. Egan, The Films of Makhmalbaf: Cinema, Politics and Culture in Iran, Washington, 2005, s. 89.

${ }^{49}$ H. Dabashi, Makhmalbaf at large. The making of a rebel filmmaker, przedmowa Mohsen Machmalbaf, London - New York 2008, s. 50.

${ }^{50}$ Mudżahedin (arab. bojownik) - mężczyzna uczestniczący w ruchu religijnym, społecznym lub wyzwoleńczym w krajach muzułmańskich. Irańscy mudżahedini stanowili jedną z grup opozycyjnych zarówno w czasach monarchii Pahlawich, jak i za rządów ajatollahów. Pod wpływem idei Szariatiego Ludowi Mudżahedini wytworzyli synkretyczną doktrynę będącą mieszanką marksizmu i szyickiego islamu. Zob. J. Tomasiewicz, Terroryzm na tle przemocy politycznej (Zarys encyklopedyczny), Katowice 2000, s. 260.

${ }^{51}$ J. de Groot, Religion, Culture and Politics in Iran: From the Qajars to Khomeini, I. B. Tauris, London 2007, s. 5.

${ }^{52} \mathrm{~S}$. Arjomand, The Turban for the Crown... dz. cyt., s. 123.

${ }^{53}$ J. Dobrzelewski, Wojna iracko-irańska 1980-1988, Wydawnictwo inforteditions, Zabrze - Tarnowskie Góry 2014, s. 22.

${ }^{54}$ Dokładna liczba ofiar nie jest znana.

${ }^{55}$ Hidżab, powszechnie identyfikowany z nakryciem głowy, de facto nie odnosi się do części 


\section{MIĘDZY PAMIĘCIĄ A HISTORIA_...}

garderoby, ale do ogólnej zasady skromn oś c i, która dotyczy nie tylko odpowiedniego ubioru, ale również sposobów zachowania. Muzułmanie wywodzą zasadę hidżabu z Koranu, ale zwyczaj zasłaniania i separacji kobiet był znany na Bliskim Wschodzie na wiele wieków przed islamem i miał charakter bardziej kulturowy niż religijny. Fadwa El Guindi umiejscawia początki hidżabu w starożytnej Mezopotamii. Zob. F. El Guindi, Veil: Modesty, Privacy and Resistance, Berg, Oxford 1999.

${ }^{56}$ M. Stolarczyk, dz. cyt., s. 166.

${ }^{57}$ Tamże, s. 169. W 2018 r. w Teheranie, po 39 latach restrykcyjne prawo uległo zmianie. Liberalizacja polega na tym, że kobiety zamiast kar będą korzystały a doradztwa. Zatrzymana będzie skierowana na szkolenia dotyczące prawidłowego ubioru prowadzone przez policję. Jeśli jednak kobieta będzie notorycznie zatrzymywana $\mathrm{z}$ tego samego powodu, wciąż może spotkać ją kara więzienia. Nowe zasady wprowadzono wyłącznie w stolicy, w pozostałych częściach kraju nadal obowiązuje dawne prawo.

${ }^{58}$ Czador jest strojem wierzchnim, zakładanym na ubranie. W 1936 r. szach Reza Pahlawi wprowadził zakaz noszenia czadoru jako stroju niezgodnego z jego ambicjami modernizacyjnymi.

${ }^{59}$ Zob. R. Czulda, Iran 1925-2014. Od Pahlawich do Rouhaniego, Wydawnictwo Naukowe PWN, Warszawa 2014, s. 104-108.

${ }^{60}$ Szahadat to zaświadczanie i poświadczanie słowem, czynami i, jeśli zachodzi taka potrzeba, ofiarą z życia. Idea szahadatu jest jedną z najbardziej żywotnych, aktywizujących się szczególnie w czasach uznanych przez muzułmanów za opresyjne wobec wyznawców islamu. Zob. S. Surdykowska, Idea szahadatu w kulturze Iranu, Wydawnictwa Uniwersytetu Warszawskiego, Warszawa 2006, s. 12.

${ }^{61} \mathrm{H}$. Godazgar, The Impact of Religious Factors on Educational Change in Iran: Islam in Policy and Islam in Practice, The Edwin Mellen Press, Lampeter - Lewiston - Queenston 2008, s. 112.

${ }^{62}$ Słowo szahid wywodzi się z języka arabskiego i oznacza świadka. W. Raven, Martyrs, w: Encyclopaedia of the Qur'ān, red. J. D. McAuliffe, t. 3, Brill, Leiden 2003, s. 281-287.
${ }^{63}$ H. Naficy, A Social History of Iranian Cinema. Volume 3: The Islamicate Period, 1978-1984, Duke University Press, Durham NC 2012, s. 31 .

${ }^{64} \mathrm{M}$. Abassy, Typy męczenników i wzory męczeństwa w szyickim islamie, w: „Kultura Słowian. Rocznik Komisji Kultury Słowian PAU”2018, t. XIV, s. 49.

${ }^{65}$ A. Lankford, Human Killing Machines: Systematic Indoctrination in Iran, Nazi Germany, Al Qaeda and Abu Graib, Lexington Books, Lanham, MD 2009, s. 105.

${ }^{66}$ I. Grelowska, dz. cyt.

${ }^{67}$ Pressbook filmu, dz. cyt.

${ }^{68}$ H. Naficy, dz. cyt., s. 4.

${ }^{69}$ M. Abassy, dz. cyt., s. 478.

${ }^{70}$ Dż. Al-e Ahmad, Qarbzadegi, Teheran 1341 (1963), s. 5.

${ }^{71}$ Tamże, s. 23.

72 Tamże, s. 474.

${ }^{73}$ Pressbook filmu, dz. cyt.

${ }^{74}$ R. Rafei, LEBANON: Iran revolution film „Persepolis” unbanned, https://latimesblogs.latimes.com/babylonbeyond/2008/03/lebanon-iran-re.html (dostęp: 2.04.2019).

75 Dynastia Achemenidów panowała w Iranie w latach 550-330 p.n.e.

${ }^{76} \mathrm{~K}$. Witas, Persepolis - miasto zagubionej tożsamości, ,Art Papier” 2008, nr 2 (98), http://artpapier.com/index.php?page=artykul\&wydanie=52\&artykul=1132 (dostęp: 12.04.2019).

77 https:/www.goodreads.com/work/quotes/13344769-persepolis (dostęp: 12.04.2019).

${ }^{78}$ H. Godazgar, dz. cyt., s. 112.

${ }^{79}$ Imperium perskie, w kształcie nadanym mu przez Cyrrusa, podbił Aleksander Wielki. Po podbojach macedońskich nastał okres hellenistyczny. Zob. B. Składanek, Historia Persji. T. 1, Od czasów najdawniejszych do najazdu Arabów, Wydawnictwo Akademickie Dialog, Warszawa 2004.

${ }^{80}$ M. Stolarczyk, dz. cyt., s. 70.

${ }^{81}$ P. Nora, Między pamięcia a historią: Les lieux de memoire, „Tytuł roboczy: Archiwum” 2009, nr 2, s. 5.

82 Tamże.

${ }^{83}$ Materiały prasowe, https://www.film.gildia.pl/filmy/persepolis/o-produkcji (dostęp: 10.04.2019). 